\title{
SCHOOL WARS: THE CONFLICT OF BRITISH EDUCATION IN THE OFFICIAL DISCOURSE AND ITS REPRESENTATION IN SUE TOWNSEND'S EARLY NARRATIVE
}

Nieves de Mingo IzQuierdo

UNED

nievesdemingo@gmail.com

\begin{abstract}
In the last decades of the twentieth century British society witnessed a ferocious attack against long-term assumptions on welfare provisions, the role of local authorities or the socalled post-war consensus that had marked the history of the country since the end of World War II. In the 1980s, the official Thatcherite discourse on family, healthcare or education was clearly aimed at dismantling the alleged persistence of Labour ideology and resulted in open confrontation between Margaret Thatcher's successive governments and the different social groups involved, the school community among them. In this last case, the conflict was so evident that it soon became literary matter, particularly when depicted by the skilful pen of Sue Townsend. In The Secret Diary of Adrian Mole Aged 13 and 3/4 (1982) and The Growing Pains of Adrian Mole (1984), the author describes in diary format the misfortunes of a neurotic, pseudo-intellectual, provincial teenager. His remarks on school impositions instilled by official policies and the subsequent reactions of some teachers and students illustrate the extent to which British schools were turned into minor battlefields, where things beyond marks, forms and course books were at stake; namely a prevailing vision of the rules of the socioeconomic game.
\end{abstract}

KEY WORDS: political discourse; conflict; school; Sue Townsend; Adrian Mole

\section{RESUMEN}

En las últimas décadas del siglo XX la sociedad británica fue testigo de un ataque abrumador a ciertos postulados históricamente asumidos relativos, por ejemplo, al estado del bienestar, el papel de las autoridades locales o el denominado «consenso de postguerra» que habían marcado la historia de Gran Bretaña desde el final de la Segunda Guerra Mundial. En los años ochenta, el discurso oficial impuesto por Margaret Thatcher sobre la familia, la sanidad o la educación tenía como objetivo evidente desmantelar la supuesta persistencia de la ideología laborista, lo que resultó en un conflicto abierto entre los sucesivos gobiernos de Margaret Thatcher y los diferentes grupos sociales implicados, entre ellos la comunidad escolar. En este último caso, el conflicto fue tan evidente que pronto se convertiría en materia 
literaria, gracias especialmente a la hábil pluma de Sue Townsend. En The Secret Diary of Adrian Mole Aged 13 and 3/4 (1982) y The Growing Pains of Adrian Mole (1984), la autora describe en formato de diario ficticio las desdichas de un adolescente neurótico, provinciano y pseudointelectual. Sus observaciones sobre las restricciones en el mundo de la escuela, inspiradas por las políticas oficiales en conflicto y la consiguiente reacción de profesores y estudiantes ilustran en qué medida los colegios británicos se estaban transformando en pequeños campos de batalla donde se dirimía una realidad más allá de notas, cursos o libros de texto; en concreto, una visión predominante de las reglas del juego socioeconómico.

Palabras Clave: discurso político; conflicto; escuela; Sue Townsend; Adrian Mole

\section{INTRODUCTION}

«We must fight the battle of ideas in every school» (Joseph, 1974). These explicit words, delivered by Sir Keith Joseph, the Conservative Spokesman on Home Affairs in 1974, as part of a speech to his party members in Birmingham provide a perfect summary of the Conservative perception of the situation of education in Britain at that time.

Behind the conflict, so succinctly depicted by Joseph, lay the collapse of the Welfare State's allegedly solid building epitomized by those discourses and counter-discourses on several paramount issues of British politics that had been alternatively sustained by Labour and Conservative politicians. In 1944, the Education Act, of a Conservative imprint, had contributed to lay the foundations of the so-called post-war consensus in the name of which ideological assumptions were smoothed over by both major political formations in order to pursue the common aim of the country's reconstruction. However, by the 1960s, some important discrepancies emerged corresponding to a change in the socioeconomic conditions and the dissolution of the catalyst for action that World War II had represented. In the 1970s, the ideological polarization of Britain tinged every single line of the political agenda and transformed the different spheres of British life into sites of open conflict. Schools were not alien to this confrontation, for both parties considered education as a top priority, despite their opposed formulations in practice. With the arrival of Margaret Thatcher at 10, Downing Street, the official policies on education radicalised as part of the Conservative programme aimed at dismantling the Labour influence at a local level. However, some Labour changes, such as the establishment of comprehensive schools, could not be demolished.

Taking this global panorama into account and not disregarding the open discussion about the true condition of literary narrative, the reading of some works by certain authors may help illustrate the zeitgeist of Thatcher's premiership as far as education is concerned. Previously, educational settings had very often featured in British literature, from Thomas Hughes's Tom Brown's School Days to Enyd Blyton's Saint Claire and Malory Towers or David Lodge's college novels, to name but a few. In these cases classrooms, boarding schools or colleges are the main and almost exclusive locations for the action. On other occasions, school is just one of the stages where action and characters interact as in Charlotte Brontë's Jane Eyre or Tom Sharpe's Wilt. In the case of Sue Townsend's early —and successful— narrative, represented 
by The Secret Diary of Adrian Mole Aged 13 and 3/4 (1982) and The Growing Pains of Adrian Mole (1984) school, as a complement of home, is a world of its own ${ }^{1}$. Students are organised in self-contained hierarchies, teachers' ideologies range from traditional right wing to open Labour positions, the Head teacher is the most faithful supporter of Thatcherism, the curriculum is adapted to any extraordinary circumstances that may come, and the additional services in schools experience progressive deterioration.

School issues are also dealt with by Townsend in other books of the Adrian Mole series of diaries, as well as in The Queen and I and in Number Ten, albeit with far less importance. However, in spite of the fact that the references constitute valuable strokes on the global painting of the British education panorama of the last decades of the twentieth century, the two first volumes of the Adrian Mole Diaries stand out as clear examples of the importance of school for both the construction of literary characters' entourage and action development and, at the same time, they allow the interested reader to learn how official policies influenced the everyday activities of the school community and, to a greater extent, of British citizenry in the time when they were written.

\section{THE BATTLEFIELD: BRITISH SECONDARY SCHOOLS AND THE FIGHT ON PUPILS SELECTION}

One of the theatres of operations of the education conflict was represented by the different secondary schools British students had to attend when reaching the age of eleven. Adrian Mole is a pupil at Neil Armstrong Comprehensive School, whose sole name takes the reader to a time of deep transformations in British education. The Education Act of 1944 had established a three tier structure of the education system based on the division of British eleven-year-old children in accordance with their previous performance. Those who had passed their 11-plus exams were recommended to attend grammar schools, whilst secondary modern schools would be attended by those not so academically successful, and technical schools were intended to impart mechanical and engineering skills. Eventually, due to economic restrictions, the system was reduced to grammar and secondary modern schools.

During the 1960s, the system of selecting children according to their academic performance was thought to reinforce class division and social inequality. Proposals supporting the comprehensive system date back to the 1920s and some experiments were carried out in the 1940s, but the full extent of the educational plan to introduce comprehensive schools via local authorities was started by the mid-1960s, spurred by the publication of the Plowden Report (1967) on the transition from primary to secondary education. The Labour government of Harold Wilson had launched the social debate on selection and, when Tony Crosland was appointed to the Department of Education, the way for the creation of comprehensive schools, that is, all-inclusive schools with no selection procedures, was free of official obstacles. The new system's philosophy is largely indebted

${ }^{1}$ For this paper I have used the joint edition of both volumes published in 1991 by Methuen. This volume includes some extra materials which allow the reader, in a way, to fill the gap between the last pages of The Growing Pains of Adrian Mole and the following major volume, Adrian Mole, The Wilderness Years (1993). 
to Labour ideology on democracy and egalitarianism: «[Children] will need to be capable of being taught, and of learning the new skills called for by the changing economic scene... and understand that in a democratic society each individual has obligations to the community, as well as rights within it». (Central Advisory Council for Education, 1967, in Dean, 2000: 2)

In 1970, before being elected as Prime Minister, Margaret Thatcher had been appointed as Secretary of State for Education in Edward Heath's government. Once in her position and in order to reduce the budget of her department, she implemented one of the most unpopular measures of the period; the banning of free milk at school for children under seven. The unfortunate measure gave her one of her many sobriquets; «Thatcher, the milk snatcher». In one of her funniest works, the alleged secret diary of a teenage Margaret Thatcher, part of The True Confessions of Adrian Albert Mole, Susan Lilian Townsend and Margaret Hilda Roberts (1989), Sue Townsend would mock the figure of a young Thatcher and the possible antecedents of this measure: «A traveller from London (...) passed on a rumour he had heard that a future socialist government would introduce free milk to schools. Father went the colour of barley and had to sit down. (...) If the filthy socialists ever do take power, I shall refuse to drink free school milk» (Townsend, 1989: 137)2. However, this would not be more than a mere anecdote but for the fact that it implied a step further in the settlement of Conservative adamant positions against both the comprehensive system and its collateral implications, and post-war assumptions on different school matters which had long been taken for granted.

However, the conflicting discourses of Labour and Conservatives had certain common ground which referred to the evident differences in children's abilities at school. In October, 1976, Prime Minister James Callaghan delivered his famous speech at Ruskin College where he stressed that:

The goals of our education, from nursery school through to adult education, are clear enough. They are to equip children to the best of their ability for a lively, constructive, place in society, and also to fit them to do a job of work. (...) There is now widespread recognition of the need to cater for a child's personality to let it flower in its fullest possible way. (Callaghan, 1976)

The idea of differences in children's ability and its implications for school organization, together with other issues such as teachers' attitudes and performance, or parents involvement in school governance, have Conservative resonances and seemed to question traditional Labour claims. The similarities with Margaret Thatcher's speech at the Institute of Socioeconomic Studies the previous year are noticeable:

I believe you have a saying in the Middle West: 'Don't cut down the tall poppies. Let them rather grow tall.'I would say, let our children grow tall and some taller than others if they have the ability in them to do so. Because we must build a society in which each citizen can develop his full potential, both for his own benefit and for the community as a whole, a society in which originality, skill, energy and thrift are rewarded, in which we encourage rather than restrict the variety and richness of human nature. (Thatcher, 1975)

${ }^{2}$ In this work, Townsend uses the form of fictive diary again to introduce the reader into an interesting metafictional game which provides a possible explanation for the future political position of Margaret Thatcher and her policies as a PM. 
Despite these few points of agreement, the Conservatives' narrative of the education conflict continued stressing the dangers of egalitarianism which they retained as the origin of the lower standards of education, remarking the apparent conflict in Labour discourse between permissiveness and state control:

Such words as good and evil, such stress on self-discipline and on standards have been out of favour since the war with the new establishment. They have preferred the permissive society, and, at the same time, the collectivised society. At first sight this paradox might seem inexplicable. Why should people who believe in strict state control over economic life, who disfavour private enterprise, independent education, private pension schemes, private medicine, so strongly favour what they call permissiveness in social life? (Joseph, 1974)

Margaret Thatcher defined Labour «comprehensivization» as «essentially social engineering and only secondarily educational» (Thatcher, 1995: 158), incurring however in a complete contradiction, as we shall see, when claiming that the most adequate way to preserve the grammar schools system was to stress «the autonomy of local education authorities», «to fight centralization» (Thatcher, 1995: 158). But apart from situational adjustment to political circumstances, what seems clear is that the whole system of Conservative beliefs about education stemmed from those persistent Victorian values whose traces are to be found even nowadays in British society, reinforced, in turn, by Thatcher's own Methodist upbringing. While emphasising the importance of entrepreneurship, creativity and the strength of individual abilities to progress, law and order were required and family discipline, ideological control and sexual morality had to be imposed. Townsend stresses this discrepancy in The Secret Diary of Adrian Mole Aged 13 and 3/4, where students' creativity is confronted by the official interference of the school Head teacher, Mr. Scruton:

I am in an experimental Nativity play at school. It is called Manger to Star. I am playing Joseph. (...) Mr. Scruton sat at the back of the gym and watched rehearsals. He had a face like the north Face of the Eiger by the time we'd got to the bit where the three wise men were reviled as capitalist pigs. (...) He took Miss Elf into the showers and had a 'Quiet Word'. We all heard every word he shouted. He said he wanted to see a traditional Nativity play with a Tiny Tears doll playing Jesus and three wise men dressed in dressing gowns and tea towels. He threatened to cancel the play if Mary, alias Pandora continued to go into simulated labour in the manger. (Townsend, 1991: 143-144)

Surprisingly, the conflicting discourses on comprehensive schooling did not result in a dismantling of the whole system under Thatcher's premiership. By the time Adrian Mole was «13 and $3 / 4 »$ the comprehensive system was generalized enough so as to allow him to be a student in one of these schools, surrounded by all types of students belonging to a wide variety of class backgrounds, from lower working class, bordering on precariat, to upper working class and lower middle class:

Mr Cherry is very pleased with my work and he has raised my wages by two and a halfpence an hour. He also offered me the Corporation Row evening round, but I declined his offer. Corporation Row is where the council put all the bad tenants. Barry Kent lives at number 13. (Townsend, 1991: 31, 41)

So now I know where Pandora lives! I had a good look at the house. It is much bigger than ours. It has got rolled-up wooden blinds at all the windows, and the rooms look like jungles because of all the green plants. (Townsend, 1991: 41) 
And diverse academic performance:

Pandora doesn't sit next to me in Geography any more. Barry Kent does. He kept copying my work and blowing bubblegum in my ears. I told Miss Elf but she is scared of Barry Kent as well, so she didn't say anything to him. (Townsend, 1991: 37)

Miss Elf said my work is perfectly satisfactory, but that isn't good enough when Pandora keeps getting 'Excellent' in red pen on everything she does. (Townsend, 1991: 159)

\section{THE COMBATANTS: OFFICIAL NARRATIVES ON AUTHORITY, FREE CHOICE AND THE PERFECT CHILD}

In the British battle for education at the time, there were different participants who were affected by official policies and discourses to a different extent, corresponding to the degree of agency they were able to display either as individuals or as members of the different groups involved in the conflict.

Once established at 10, Downing Street, Margaret Thatcher continued attacking the comprehensive school system as a result of a major conflict with left-wing institutions, this time exemplified by the local councils which had been responsible for education through the articulation of the so-called LEAs, (Local Education Authorities) and were considered mainly left-wing realms: «I had much more radical options in mind (...) Essentially this would have meant the dismantling of many of the LEAs' powers, leaving them with a monitoring and advisory role -perhaps in the long term not even that» (Thatcher, 1995: 597). To nullify the content of the LEAs and give greater authority to government officials and parents, Thatcher's governments used, among other weapons, the media at hand, especially papers like The Sun or the Daily Mail that published a number of stories about the alleged absurdities committed in schools by the «loony left» (Negrine, 1989). However, despite her many efforts, Thatcher seemed to acknowledge that «the ethos in classrooms and teachers' training colleges remained stubbornly left wing» (Thatcher, 1995: 306). ${ }^{3}$ Therefore, part of the devised solution consisted in giving more control to Head teachers of budgetary and organisational powers (Edwards, 1989). In the case of Neil Armstrong Comprehensive School, Mr. Scruton imposed his power by all the possible means at his disposal, inflamed by the Thatcherite cult:

This morning the whole school was ordered to go to the assembly hall. Mr. Scruton got up on the stage and acted like the films of Hitler (...) Scruton said that somebody had entered his office and drawn a moustache on Margaret Thatcher and written 'three million unemployed' in her cleavage. He said that defiling the greatest leader this country has ever known was a crime against humanity. It was tantamount to treason and that when the culprit was found they would be immediately expelled. (Townsend, 1991: 165)

3 My emphasis. 
This insistence on the figure of the Head teacher on the part of official policies might have been influenced by the Tyndale affair. Back in July 1975, the events at William Tyndale Junior School were the cause of open controversy on education and the role of Head teachers and teachers. The school managers were denied their right to inspect the school after some new methodologies had been put into practice by teachers who, up to that moment, were retained as the only ones in charge of determining the curriculum of the school. Things got progressively worse and teachers went on strike while the main newspapers of the country took advantage of the conflict according to their own ideology (Riley, 1998). The results were that the authorities at school were reinforced and striking teachers were banned from school. The echoes of the conflict helped, undoubtedly, to reinforce the position of Head teachers as the highest power at schools, although some students resented this authoritative position: «This is typical of Scruton, he is nothing but a small-minded, provincial, sexually-inhibited fascist pig. How he rose to became a Head teacher I do not know» (Townsend, 1991: 144).

Teachers were an active part in the school wars of the time, particularly through their unions. ${ }^{4}$ They had been deeply questioned, and for the first time were subjected to public scrutiny and were perceived mostly as left-wing activists who took advantage of their positions to indoctrinate children into leftish ideas (Abbott, Rathbone \& Whitehead, 2013). It seems undoubtedly that some teachers may have responded to this portrait of the Conservatives: «Miss Elf said that school-leavers are despairing all over the country. She said that Mr. Scruton should be ashamed to have a portrait of Mrs. Thatcher over his desk» (Townsend, 1991: 164). Clearly, Miss Elf was the complement — not the counterpart- of Mr. Scruton at Neil Armstrong Comprehensive. She is described as a non-racist, left-wing, open-minded and devoted teacher:

School was closed this morning because the teachers couldn't manage to get in on time (...) Miss Elf lives with an East Indian in a terraced house in the town, so she bravely turned out to prepare for the school concert. (...) Only two shopping days left for Christmas and I am still penniless (...) I have made a Blue Peter oven-glove for Miss Elf, but in order to give it to her in time for Christmas I will have to go into the ghetto and risk getting mugged (Townsend, 1991: 147, 148)

Miss Elf will confront Mr. Scruton with all her strength and to the latest consequences:

This morning the whole school was ordered to go to the assembly hall. (...) He [Mr. Scruton] said that defiling the greatest leader this country has ever known was a crime against humanity. It was tantamount to treason and that when the culprit was found they would be immediately expelled. (...) Miss Elf has resigned. I will miss her, she was responsible for my political development. I am a committed radical. I am against nearly everything. (Townsend, 1991: 165)

Students were the ones to play second fiddle in the school wars. They were subjected to the changing government policies which ranged from open methodological experiments to going back to basics in the formulations of the school curriculum. What Conservatives resented was the child-centred teaching methods experienced by «the bully-boys of the left» (Joseph, 1974):

\footnotetext{
${ }^{4}$ See Pilcher \&Wagg, Eds., 1996.

${ }^{5}$ My emphasis.
} 
[Margaret Thatcher's] first priority on returning to office in 1987 was to attack what she saw as the rot in the state education system, especially the new 'child centered' teaching techniques, the emphasis on stirring children's imaginations rather than making them learn facts, and the blurring of subjects into wider entities like 'humanities'. (McSmith, 2011: 188)

However, when given the opportunity, the students tried their best to display their imagination, albeit with uneven results:

Then the music from Close Encounters boomed out over the stereo speakers and the curtains opened on an abstract manger (...) My performance was brilliant! (...) The three punks/ wise men made too much noise with heir chains and spoiled my speech about the Middle East situation, and the angels representing Mrs. Thatcher got hissed by the audience so loudly that their spoken chorus about unemployment was wasted. (...) Still all in all, it was well received by the audience. Mr Scruton got up and made a hypocritical speech about 'a brave experiment'. (Townsend, 1991: 147)

As we can see, Townsend's construction of the Neil Armstrong Comprehensive students is directly opposed to the ideal of the perfect student/child envisaged by Conservative propaganda. She describes a group of youngsters experiencing political involvement and fully aware of the situation of the country, clearly a result of both the influence of Miss Elf's approach to education and the perception of the reality around them: «My father had a letter that made his face go white: he has been made redundant from his job!. He will be on the dole! (...) I am now a single-parent child whose father is on the dole! Social Security will be buying my shoes!» (Townsend, 1991: 79).

\section{GUERRILLA WARFARE: MICRO-LITERARY REBELLIONS.}

In every war there are always unofficial actions which do not respect the rules of engagement. In The Secret Diary of Adrian Mole Aged 13 and $3 / 4$, Townsend describes, with her usual doses of humour, one of the most noticeable in the whole existence of Neil Armstrong Comprehensive: «the red socks protest», which proves the extremely limited scope of students' contestation and, once again, the authoritarian position of the Head teacher:

I went to school, I was feeling rebellious so I wore red socks. It is strictly forbidden but I don't care any more (...) Miss Sproxton spotted my red socks in assembly! The old bag reported me to pop-eye Scruton. He had me in his office and gave a lecture on the dangers of being a nonconformist. Then he sent me home to change into regulation black socks. (Townsend, 1991: 80)

Far from being discouraged, students react by arranging themselves in an organised committee with mannerisms quite similar to the highly criticised by Conservatives «industrial action», despite the more than secure fifth-columnists that alerted the authorities:

Pandora is organizing a sock protest! She is going round the school with a petition on Monday morning. She said I was a freedom fighter for the rights of the individual.(...) Met Pandora and rest of the committee at corner of our road; all of us were wearing red socks. (...) We sang 'We shall not be moved' all the way to school. (...) Pop-eye Scruton must have been tipped off because he was waiting in the fourth-year cloakroom. (Townsend, 1991: 81, 82) 
Unfortunately for Adrian and his peers, rebellion is crushed by Scruton in the most painful way, by reporting to their parents:

The letter was to our parents, it said:

Dear Mr and Mrs

It is my sad duty to inform you that your son/daughter has deliberately flaunted one of the rules of this school. I take an extremely serious view of this contravention. I am therefore suspending your son/daughter for a period of one week. (Townsend, 1991: 82)

However, insurgency resists, in quite an uncomfortable way: «The Red Sock Committee has voted to give way to Scruton for the time being. We wear red socks underneath our black socks. This makes our shoes tight but we don't mind because a principle is involved (Townsend, 1991: 85); or later by literary action flowering on the walls of the school toilets thus allowing Townsend to turn school into a site of - comic - political contestation:

I wrote a poem on the toilet wall at school today.

I thought it was a good way of getting a bit of political consciousness over to my moronic fellow pupils.

The Future

What future is there for the young?

What songs are waiting to be sung?

(...)

No jobs to go after school.

We divide and still they rule.

They give us Job Creation Schemes.

When what we want are hopes and dreams

(Townsend, 1991: 284)

Poor Adrian was completely unaware of the fact that students were required not to express their political opinions but to quietly abide by the role they had been imposed as mere recipients of practical knowledge as depicted by the official construction of their image. Once again, Mr. Scruton erases any possibility of insubordination. This time it was really easy for him, though: «I was sent to see the headmaster today. He has found out about my toilet poem. I asked him how he knew I'd written it. He said, 'You signed it, idiot boy.' I have been suspended for a week» (Townsend, 1991: 331)

The last, but not the least valuable contenders in the battle of education were the parents who found themselves in the limelight thanks to the new protagonist position the Conservative party had reserved for them in their global scheme of education. Parents were given a relevant role in education via the most-valued concept of «parental choice», which referred to the possibilities of parents choosing the council school they preferred for their children, among the different possibilities at hand and by using government vouchers. Lowe (2002) interestingly links this idea to the betterment of the economic situation with respect to previous decades which turned parents into consumers of education services as 
part of the market socioeconomic apparatus. In practice the choices were very limited for working class parents and benefitted the middle classes hoping to distance themselves from lower class parents. Adrian Mole's parents had very little scope of agency when choosing a school for their son. Both coming from a working class environment and living in a suburb of Leicester, the range of possibilities they were offered for Adrian's schooling was limited to the Comprehensive in their neighbourhood. In this sense, Lowe links the presence and characteristics of schools to housing policies and the sort of «self-sifting» process that house prices determined as far as schools are concerned, which, in turn, influenced the social composition of the student body.

In addition, the use and abuse of the Thatcherite conception of «parental responsibility» was remarkable in the national debate on education and introduces one of the many contradictions evidenced by the philosophy of the New Right as noted by Jagger and Wright (1999): the need for the State to control the personal behaviour of parents so as to define the binding character of their responsibility, and the general atmosphere of «laissez-faire» that Thatcherism proclaimed as the essential breeding ground for national improvement. It seems that the authorities needed to remind parents of their responsibilities when their children confronted official postulates. So it was described in the Children Act of 1989 and in both the Criminal Justice Act of 1991 and the Criminal Justice and Public Order Act of 1994 (Fox Harding, in Jagger \& Wright (eds.), 1999). And so it was remarked by Mr. Scruton:

The letter was to our parents, it said:

Dear Mr and Mrs

(...) Young people today often lack sufficient moral guidance in the home, therefore I feel that is my duty to take a firm stand in my school. (Townsend, 1991: 83)

Both parents and children were the essential components of the Thatcherite construction of the family as the unit around which society is conformed. Thatcher's favourite family is traditional, self-reliant, and patriarchal, with well-defined roles to be performed by its members: father as the breadwinner, mother as the home-maker, children as the product of their heterosexual love and born within wedlock. Single parents, particularly mothers, were out of the picture and considered to be the detritus of a malfunctioning welfare state. Townsend criticises repeatedly this alleged model of ideal Thatcherite family in various ways. On the one hand, by placing Adrian Mole in the context of a dysfunctional family which, nevertheless, does not impede their members from displaying love and affection when necessary:

My mother has just turned up with no warning! She had all her suitcases with her. She has thrown herself on the mercy of my father. My father has just thrown himself on the body of my mother. I tactfully withdrew to my bedroom (...) My mother and father are in bed again and it's only 9 p.m.! The dog is very pleased my mother is back. It has been going about smiling all day. (Townsend, 1991: 139)

On the other hand, by marking the fact that parents who do not respond to the official model so dear to the Conservatives do show the same love, concern and respect for their children as the rest, for these are the main components of family: 
Baz [Barry Kent] took me home and introduced me to his family today. Mrs. Kent said, 'Ain't you the lad what's ad all the scandal?I said, 'Yeah that's me, but so what?' Mrs. Kent said, 'That's no way to talk young man'. Mr. Kent said, 'You keep a civil tongue in your head. That's my wife you are talking to.' I immediately apologized and remembered my manners. In fact I got up and offered Mrs Kent the unbroken chair. (...) A lurid coloured photo of Clive Kent in his army uniform stood on top of the radiogram. (...) Mrs. Kent said, 'he's in an army hospital: his nerves are short to pieces after the Falklands.' I had a nice tea with the family. (Townsend, 1991: 331)

\section{DEPLOYING THE TROOPS: THE CONSTRUCTION OF NATIONHOOD AT SCHOOL}

10 AM. Woke my father up to tell him Argentina has invaded the Falklands. He shot out of bed because he thought the Falklands lay off the coast of Scotland. When I pointed out that they were eight thousand miles away he got back into bed and pulled the covers over his head. (Townsend, 1991: 175)

On Friday, 2 April, 1982, Argentina invaded British territories in the South Atlantic, the Falklands. The following days, Argentinian troops also set foot on and claimed South Georgia and the South Sandwich Islands. The British government retaliated by sending troops. The war started, and in one month and a half Argentina surrendered and the islands returned to British sovereignty. This brief description of a well-known conflict must not disregard the profound impact it had on both countries, either as a political weapon to mask the outrage of Argentinian dictatorship and to serve Thatcher a second term on a silver platter or as an open wound in the lives of many families of both countries with casualties among their members.

British schools were never alien to the extreme measures taken by governments according to the fluctuations of their foreign policies; from World War II evacuations to Cold War drills for civil defence training, schoolchildren had been the specific object of certain dispositions in order to preserve their integrity. At the same time, students had been subjected to a variety of influences through comic and cinema regarding the issue of war: «8 AM. Britain is at war with Argentina!!! Radio Four has just announced it. I am overcome with excitement. Half of me thinks it is tragic and the other half of me thinks it is dead exciting» (Townsend, 1991: 175). These contradictory feelings Adrian Mole is experiencing are due to the acknowledgement of the tragedy of an event that, according to Paris, «cinema and literature had satanized, romanticized and turned into thrilling adventure» (2000: 236).

In the 1980s the Falklands conflict revived those war anxieties which in the British context came hand in hand with old World War II narratives, this time sieved through Thatcherite constructions of nation. It gave Thatcher the opportunity to appear as a war leader steeped in Churchillian rhetoric and heal the wounds still open from the Suez crisis of 1956:

We have ceased to be a nation in retreat. We have instead a new found confidence. (...) We rejoice that Britain has rekindled that spirit which has fired her for generations past and which today has begun to burn as bright as before. Britain found herself again in the South Atlantic and will not look back from the victory she has won. (Thatcher, 1993: 235) 
According to Paris there were worried reactions in the aftermath of the war regarding the major support an «unnecessary war» had gained (Paris, 2000: 250). However, at Neil Armstrong Comprehensive School, the discussion on the conflict was open, opposing the general tendency to support it stemming from the extreme censorship the government practised on images and news of so far away a conflict. Townsend describes a clear-cut divide between sensitive minds, representatives of a pacifist trend supported by literary antecedents that lead to further reflection on the results of official manipulation, and the modelling of common people's opinions to obtain the desired political effect on the grounds of national interests.

We had a dead good debate in Social Studies this morning. It was about the Falklands. Pandora put the proposition 'That this class is against the use of force to regain the Falkland Islands. (...) I made a brilliant speech in favour of the motion, I quoted from Animal Farm and The Grapes of Wrath ${ }^{6}$. (...) Barry Kent [the school bully] spoke against the proposition. He said 'Er, I er, fink we should, er, you know, like, bomb the coast of Argentina' He was quoting from his father.' (Townsend, 1991: 196)

At school the conflict is discussed and hard words are exchanged between pacifists, some teachers among them, and those supporting the government's war machine:

Barry Kent came to school in a Union-Jack tee-shirt today. Ms. Fossington-Gore sent him home to change. Barry Kent shouted, 'I'm celebratin' our patron saint's birthday ain't I?' Mrs. Fossington-Gore shouted back, 'You're wearing a symbol of fascism, you nasty NF lout.' (Townsend, 1991: 198)

Barry Kent's clothing and attitude should have been so common as to immediately allow the readers of the 1990s, that is some years after both the conflict and the publishing of The Growing Pains of Adrian Mole, to link them to those of the characters' in Charles MacDougall's film Arrivederci Millwall (1990), which proves that Townsend, like other authors and filmakers, equated uneducated hooliganism displayed through violence, racism and xenophobia to the support of an unnecessary war. In this sense, Monaghan stresses that «many of them had connections with the National Front, football hooligans were even amongst the group of potential voters whose support Thatcher had sought by adopting racist policies in the late 1970s» (Monahan, 1998: 101)

In addition, Townsend's acute pen targets pro-war media reactions to the student's exaltation of the characteristic set of national symbols by mocking the journalistic style of the most inveterate Thatcherite papers:

Barry Kent's father is on the front of the local paper tonight. He is pictured holding Barry Kent's Union Jack tee-shirt. The caption underneath his picture says: 'A patriot mourns loss of National Pride'

Burly World War Two veteran Frederick Kent (45) spoke to our reporter in his homely council house lounge about his profound feelings of regret that his son Barry (15) was ridiculed and humiliated because he wore a Union Jack tee-shirt to school. Barry is a pupil at Neil Armstrong Comprehensive School. (...) Mr Kent is refusing to let his son attend school until the teacher concerned, Ms. Fossington-Gore (31) makes a public apology. (Townsend, 1991: 198)

\footnotetext{
${ }^{6}$ No italics in the original
} 
The whole extract displays a set of micro-components which contribute to creating the global impression of what the conflict in the South Atlantic and in schools in the home front meant to Townsend. The reader cannot fail but to notice the improbability that Barry's father had fought in World War II if he is only 45. However, the newspaper links directly the Falklands conflict with World War II, thus connecting the former with the British myths of resistance and prevalence originated by the latter. It seems clear that the headline is very much in line with The Sun or The Daily Mail and their open pro-war campaign. Equally, to stress the allegedly anti-British attitude of the teacher, the terms «ridicule» and «humiliation» are extended to the Union Jack as the symbol of Englishness. Mrs. Fossington-Gore is 31, which implies she belongs to the generation that lived throughout the peace movements of the 1970s and is therefore depicted as a dangerous pacifist by Barry's father. In addition, she must apologise for being disrespectful to the boy and, to a greater extent, to the Union Jack and therefore, the whole country. To complete the loop, according to the paper, council houses do have lounges and are homely. According to the news, the interview takes place in the same council house where Adrian offered the only useful chair to Mrs. Kent.

However, it seems that in Neil Armstrong Comprehensive the seed of pacifism: «Got fifteen out of twenty for Geography. I lost points for saying that the Falkland Islands belonged to Argentina» (Townsend, 1991: 166), and anti-government politics has sprout:

Mr. Lambert told me off for staring out of the window when I should have been writing about the future of the British Steel Industry. He said, 'Adrian, you've only got ten minutes to finish your essay'. So, I wrote: 'In my opinion there is no future for the British Steel Industry while the present government is in power.' I know I'll get into trouble, but I gave it in anyway. (Townsend, 1991: 285)

Eventually, what Townsend conveys is the sad results of a war that, unfortunately for Adrian's generation, was not going to be the last in which Britain would be involved : «I took the dog round to Bert's and watched the Falklands Memorial Service on television. St. Paul's cathedral was full of widows and bereaved people. I went home and chucked my Falklands campaign map in the bin» (Townsend, 1991: 241).

\section{COLLATERAL DAMAGE: THE AGGREGATED SOCIAL IMPACT OF THE FIGHT FOR LOCAL POWER}

Pandora and Craig Thomas are creating a scandal by flaunting their sexuality in the playground. Miss Elf had to knock on the staff-room window and ask them to stop kissing. (Townsend, 1991: 68)

Teenage sexuality and its accompanying frustration, desire and experimentation is fully acknowledged by Townsend in The Secret Diary of Adrian Mole Aged 13 and 3/4 when Adrian's sexual awakening is described in a common, humorous, matter-of-fact way; responding fully to the alleged comments written by a teenager in his diary, and given the same importance as the rest of the existential events which Adrian interprets under his usual negative prism. However, his remarks on the topic prove to be quite interesting when analysing the world of education in the British context of the 1980s, for sexual education 
was not properly addressed in the school curriculum due to the traditional Conservative postulates which, nevertheless, regulated certain aspects to an extent that it took years to legally overcome.

In this sense, dealing officially with sexual education at school reflected «the problematic interaction of the State with moral issues and shifts in the nature of the family and sexuality» (Sauerteig \& Davidson in Sauerteig \& Davidson, Eds., 2008: 6). Thus, the official Thatcherite discourse on the topic focused on fear stemming from disease spread or teenage pregnancy, and turned around family and moral values. However, prior Labour policies on family planning, contraception or abortion had not been accompanied by a proper development of sex education at schools.

Before 1986 the tuition of sexual education at schools and the programme of the subjects was a personal decision of headmasters. The stance taken by Mr. Scruton at Neil Armstrong Comprehensive is very clear: «Pandora and Craig Thomas are creating a scandal (...) Mr. Scrutton made a speech in assembly this morning. It was about the country's lack of morals, but really he was talking about Pandora and Craig Thomas»(Townsend, 1991: 68).

Wishing to snatch education control from the LEAs' hands, Thatcher's government designed the Education Act of 1986 where sex education is explicitly alluded to regulate not the contents of the subject but the manner in which it had to be imparted so as to:

Secure that when sex education is given to registered pupils at maintained schools:

(a) They learn the nature of marriage and its importance for family life and the bringing up of children, and

(b) they are protected from teaching and materials which are inappropriate having regard to the age and the religious and cultural background of the pupils concerned. (Education Act, 1986)

The Education Act marginalized the role the LEAs played in education control and left all matters regarding sexual education in the hands of the ruling body of each centre. In addition, these provisions, particularly those of section (b), will be of greater importance when dealing with the thorny problem of homosexuality and its apparent promotion in council schools. The issue had also been addressed by Townsend with her usual display of wit and humour: «Everyone is saying that Nigel is gay so I made sure that everyone knew that he is no longer my best friend» (Townsend, 1991: 306).

Private gay sex had been decriminalised in 1967, but the age of consent still was higher than in the case of heterosexual and lesbian sex, which was set at sixteen. Prior to the passing of the decriminalisation law, polls indicated that about $60 \%$ of respondents thought that «homosexual behaviour between consenting adults in private should no longer be a criminal offence»(Grey, 1989:38). However, this apparent openness was not complete as it was legally restricted to the private realm. During Thatcher's premiership, her Conservative government included the -later so-called- «infamous» Section 28 (Blair \& Monk in Sauerteig \& Davidson, eds., 2008: 39).

Once more, Townsend's acute sense of social matters anticipated, in a way, what the hot issue of the hour would be: «Nigel has formed a gay club at school. He is the only member so 
far, but it will be interesting to see who else joins. I noticed Brain Box Henderson hovering around the poster looking worried» (Townsend, 1991: 318).

In October 1987, Margaret Thatcher delivered these words in a speech for the Conservative Party Conference: «Children who need to be taught to respect traditional moral values are being taught that they have an inalienable right to be gay» (Thatcher, 1987). The, apparently, deviated educational policies established by councils were the pretext for Thatcher to increase her attacks against them and their educational policies; it is what Grey defines as the «bogus pretext»:

Section 28 is based on a bogus prospectus, but expresses real concerns. The bogus pretext was a handful of trumped-up and largely fictional cases of alleged 'promotion' of homosexuality by a few left-wing councils who had appointed gay rights committees anti-discrimination study groups, and so forth. (Grey, 1989: 56)

The casus belli had its origins in the contestation to some official positions regarding gender, race and sexuality that some sectors of British society had begun. Local councils, as the ones retained responsible for education, searched for different ways to solve these inequalities, in addition, taking into account the number of votes that these groups represented. For this reason, they started to publish different volumes in which issues related, for instance, to homosexuality addressed these topics in an open way despite having been designed for schools. Conservative media intervened in the conflict taking sides against the LEAs and in 1983 the Daily Mail published an article denouncing that Jenny lives with Eric and Martin, a book about a girl living with her father and his gay partner, was available on the library shelves of one school in London. Conservatives continued attacking what they considered attempts by Labour councils to render homosexuality a normal issue, therefore campaigning against the alleged promotion of homosexuality in schools. Eventually, Section 28 was added to section 2 of the Local Government Act of 1989:

The following section shall be inserted after section 2 of the Local Government Act 1986 (prohibition of political publicity):

Prohibition on promoting homosexuality by teaching or by publishing materials(1) A local authority shall not-

(a) intentionally promote homosexuality or publish material with the intention of promoting homosexuality.

(b) promote the teaching in any maintained school of the acceptability of homosexuality as a pretended family relationship.

2) Nothing in subsection (1) above shall be taken to prohibit the doing of anything for the purpose of treating or preventing the spread of disease ${ }^{7}$. (Cited by Wright and Reinhold in Shore, Wright \& Peró, 2011: 88)

This was a further step in the conflict between Conservatives and Labour local councils and it seems just a secondary issue, but, as Wright and Reinhold state, Section 28 «was the

\footnotetext{
7 The presence of AIDS had been already acknowledged in several laws and recommendations of various kinds.
} 
first legislation directed against a sexual identity in Britain» (2011: 88), and it was the cause of an incredible wave of response from different sectors. The wound was not closed until its repeal in 2000 in Scotland and 2003 in the rest of the country. In the name of his party, David Cameron explicitly apologised in public in 2009.

In the meantime, Townsend's humour dismantles Mr. Scruton's adamant position towards Nigel's gay club and mocks the authority of headmasters moved by their extreme Thatcherite ideology:

Nigel pretended to be innocent. He said, 'But sir, the Gay Club is for pupils who want to be frisky, frolicsome, lively, playful, sportive, vivacious or gamesome during the dinner break. What is immoral about gaiety?

Mr. Scruton said, 'Nigel, the word «Gay» has changed its meaning over the past years. It now means something quite different.

Nigel said, 'What does it mean, sir?'

Scruton started sweating and messing about with his pipe, and not answering, so Nigel let him off the hook by saying, 'Sorry, sir, I can see that I will have to get an up-to-date dictionary.' (Townsend, 1991: 318)

\section{CASUALTIES: THE CONSEQUENCES OF THE CONFLICT}

When conflicts end and armistices are signed, the time comes to evaluate gains and losses, report casualties and start reconstruction. In the case of British education, the political conflict between Labour and Conservatives during the 1980s, fought through several draconian government measures and counteracting discourses from both sides, left an indelible mark on British society. Thatcherite creed and its insistence on traditional family values and, at the same time, the confidence in the individual capacities of the self within a market context, pervaded political affairs for a long time, even under New Labour. On the other hand, neither Thatcher's attacks on comprehensive schools nor Cameron's denial of the possible building of new grammar schools (Stewart \& Walker, 2016) on the grounds of parents' rejection to 11-plus selection seemed to have turned back the clock to an age prior to the design of the comprehensive school system. However, the debate on education has been re-opened by Theresa May in September 2016 with her announcement of the reinstatement of grammar schools as the flagship of a major set of changes in British education, claiming that she wanted all children «To have the opportunity to go as far as their talents will take them» (Culbertson \& Baldwin, 2016), thus insisting on the Thatcherite discourse of «letting the children grow tall» and the rhetoric of individual potentialities not to be contravened by partisan policies.

Nevertheless, the gloomiest consequence of the school wars refers to the improvements of the levels of education and students' performance. During the time span this paper covers, neither Thatcher's fight against local authorities nor the subsequent New Labour policies represented by the Blairite motto «education, education, education» resulted in a betterment of the students' levels. In this sense, the 20th report of British social attitudes, in its analysis 
of British education under Thatcher and Blair, explicitly states the very few changes accomplished on educational issues.

The existing grammar and secondary schools survived (...) The national curriculum and the national tests (...) were left intact (...) The shift from local to central control continued (...) and the trend for more and more pupils to go to university accelerated, until the participation rate had almost trebled. (Wragg and Jarvis in Park et al. 2003 109)

A reality sadly depicted by Townsend both in the year 1982: «The school are making me read The Lord of the Flies by William Golding. I am sharing a book with three dumbos who take half an hour to read one page, so it is turning out to be a frustrating experience. (Townsend 1991 282) and in the year 1999: «I've only just realized that Glenn can't read properly. Inside the shed was a bag that clearly said 'John Innes Potting Compost'. When William asked Glenn what was inside the bag, Glenn was at a loss. 'I can't read words like that,' he said» (Townsend, 1999: 311).

Independently of the theoretical perspective adopted to consider the world of education and its variety of components, what seems undeniable is that school is not an isolated realm which remains untouched by the fluctuations of official and usually ideologically biased policies. In this sense, British education suffered the consequences of the political conflict that marked the development of the country from the late 1960s onwards, when the effects of the post-war consensus were starting to vanish. In the 1980s, Margaret Thatcher's fight to weaken local power made one of its theatres of operations the world of schools. The impact of this open conflict was perceived and depicted in different formats and by a variety of social actors, journalists, writers and intellectuals being, in general, the most active. Among them, Sue Townsend, through the allegedly naive remarks of her literary creation, Adrian Mole, stands out as one of the wittiest and most perceptive chroniclers of this long-lasting confrontation whose consequences are still discussed in British political circles.

\section{REFERENCES}

Abbott, I., Rathbone, M. \& Whitehead, P. (2012). Education Policy. London: Sage Publications.

Blair, A., \& Monk, D. (2008). Sex Education and the Law in England and Wales. In Sauerteig, L. D. \& Davidson, R. (eds.), Shaping Sexual Knowledge: A Cultural History of Sex Education in Twentieth Century Europe. New York and London: Routledge. 37-49.

Callaghan, J. (1976, October 18). A rational debate based on the facts. [Speech]. Retrieved from. http://www. educationengland.org.uk/documents/speeches/1976ruskin.html

Culbertson, A. \& Baldwin, P. (2016, September 10). «Theresa May announces biggest shake-up of British education system in 50 years». The New Statesman. Retrieved October, 27, 2016 from. http://www.express. co.uk/news/politics/708928/Theresa-May-shake-up-British-education-system

Dean, J. (2002). Improving Children's Learning: Effective Teaching in the Primary School. London and New York: Routledge. 120-135.

Fox Harding, L. (1999). Family Values and Conservative Government Policy: 1979-97. In Jagger, G. \& Wright, C. (eds.), Changing Family Values. London and New York: Routledge.

Grey, A. (1997). Speaking Out: Writings on Sex, Law, Politics and Society (1954-1995). London: Cassell.

Hall, L. A. (2008). Ignorance and Knowledge. Reflections on the History of Sex Education in Britain. In Sauerteig, L.D. \& Davidson, R. (eds.), Shaping Sexual Knowledge: A Cultural History of Sex Education in Twentieth Century Europe. New York and London: Routledge.19-34. 
Joseph, K. (1974, October 19). Our Human Stock is Threatened.[Speech]. Retrieved from http://www. margaretthatcher.org/document/101830

Local Government Act, Section 28. Retrived from http://www.legislation.gov.uk/ukpga/1988/9/section/28

Lowe, R. (2002). Schooling and Social Change.1964-1990. London and New York: Routledge.

Mcsmith, A. (2010). No Such Thing as Society: A History of Britain in the 1980s. London: Constable and Robinson. Monahan, D. (1998). The Falklands War: Myth and Countermyth. London: Palgrave.

Negrine, R. (1994). Politics and the Mass Media in Britain. London and New York: Routledge.

PARIS, M. (2000). Warrior Nation. Images of War in British/ Popular Culture, 1850-2000. London: Reaktion Books.

Pilcher, J. \& WAGG, S. (1996). Thatcher's Children?. In Pilcher, J. \& Wagg, S. (eds.). Thatcher's Children? Politics, Childhood and Society in the 1980s and 1990s. London: Falmer Press. 1-7.

Riley, K. A. (1998). Whose School is it Anyway? Power and Politics. London: Falmer Press.

Stewart, W. \& Walker, P. (2016, September 9). «Theresa May to end ban on new grammar schools». The Guardian. Retrieved October, 27, 2016 from http://www.theguardian.com/education/2016/sep/09/theresa-may-to-end-banon-new-grammar-schools

Thatcher, M. (1987, October 9). Speech to Conservative Party Conference. Retrieved from http://www. margaretthatcher.org/document/106941

- (I995). The path to power. New York: Harper Collins.

Townsend, S. (1989). The True Confessions of Adrian Albert Mole, Susan Lilian Townsend and Margaret Hilda Roberts. London: Penguin.

- (I99I). Adrian Mole, from Minor to Major. The Mole Diaries: The First Ten Years. London: Methuen.

- (I999). The Lost Diaries of Adrian Mole, from minor to major (1999-2001). London: Penguin.

Wragg, T. \& Jarvis, L. (2003). Pass or Fail? Perceptions of Education. In PARK, A. et al. (eds.), British Social Attitudes. The 20th Report. Continuity and Change over Two Decades. London: Sage Publications. 2-43.

Wright, S. \& Reinhold, S. (2011). «Studying through», A Strategy for Studying Political Transformation or Sex, Lies and British Policies. In Shore, C., Wright, S. \& Peró, D. Policy Worlds: Anthropology and the Analysis of Contemporary Power. New York and Oxford: Berghahn Books. 86-97. 